\title{
The Value Relevance of Book Values, Earnings and Cash Flows: Evidence from Korea
}

\author{
Gee-Jung, Kwon (Corresponding author) \\ Department of Taxation and Accounting, Silla University \\ San 1-1, Gwaebop-Dong, Sasang-Gu, Busan, Republic of Korea \\ Tel: 82-51-999-5438Ｅ-mail: geejung@silla.ac.kr
}

\begin{abstract}
The purpose of this paper is to investigate the relative and incremental value relevance of book value, earnings and cash flows in security prices. The study basically uses Myers (1977), Ohlson (1995) and Feltham and Ohlson (1995) valuation model and the paper performs analyses for all samples divided into profit/loss firms and earnings managed/non-earnings managed firms to observe changes in value relevance over the periods of 1994-2005 in Korean stock markets(4,865 firm-year observations).

The empirical results of the paper indicate that book value is the most value relevant variable and cash flows have more value relevance than earnings in all samples, subsamples and periods. The results also show that combined value relevance of book value and cash flows is more value relevant than that of book value and earnings, suggesting that cash flows can be a substitute for earnings in equity valuation model. The important contribution of the study is documenting the deteriorated value relevance of earnings and the increased value relevance of cash flows in equity valuation. This may be just limited to the period of 1994-2005 in Korean stock markets, or this could be the true pattern in which earnings play no significant role in security prices.
\end{abstract}

Keywords: Korean, Cash flows, Book value, Earnings, Value relevance

\section{Introduction}

The paper reinvestigates the value relevance of book value, earnings and cash flows in security prices from 1994 to 2005 in Korean stock market. The study is motivated by recent empirical literatures on value relevance including Biddle et al. (1995), Ohlson(1995), Fetham and Ohlson(1995), Hayn(1995), Amir and Lev(1996), Burgstahler and Dichev(1997), Collins et al. (1997), Hand and Lansman(1999), Yee (2000), Jang et al. (2002), Choi et al. (2006) and among others.

According to Statement of Financial Accounting Concepts (SFAS) No. 1 (FASB 1983) "Objectives of Financial Reporting by Business Enterprises," mainly focuses on accrual earnings not cash flows because accrual earnings provide more value relevant information than cash flows in predicting an enterprise's future cash flows.

But many literatures have raised questions about information contents and value relevance of accrual earnings (Lev 1989; Hayn 1995; Amir and Lev 1996; Collins et al. 1997; Jang et al. 2002). For example, Hayn (1995) finds a much weaker information contents of earnings for loss firms (those reporting negative earnings in financial statements) than profit firms (those reporting positive earnings in financial statements). And Collins et al. (1997) finds that value relevance of 'bottom line' earnings has declined.

In Korea, Jang et al. (2002) report that the incremental explanatory power of book values increase, while that of earnings decrease from 1981 to 2000. Choi et al. (2006) report that accrual earnings are more value relevant factor than cash flows in the growth stage, but in the decline stage, cash flows are more value relevant than earnings.

Since cash flows are also primary information factor in financial statements, this study basically assumes that cash flows may provide incremental information content and have additional explanatory power in stock prices like earnings and book value. The paper investigates following research questions:

First, what is the most value relevant variable among book value, earnings and cash flows in firms' valuation model? Second, has the value relevance of book values, earnings and cash flows increased or decreased? Third, when firms do earnings management and earnings manipulation to avoid reporting losses and profits decreases, what is the most value relevant variable among book value, earnings and cash flows? Forth, when firms have negative earnings, what is the 
most value relevant factor among book value, earnings and cash flows? Finally, can cash flows take the place of earnings in firms' valuation model?

To this end, the paper investigates the relative and incremental value relevance of book value, earnings and cash flows for firms listed in Korean stock markets over the period of 1994-2005. For this test the study basically uses Myers (1977), Ohlson (1995) and Feltham and Ohlson (1995) valuation model.

The paper uses multiple regression models of equity value and book value/earnings/cash flows to investigate relative and incremental value-relevance among book value, earnings and cash flows. The paper performs analyses for all samples divided into profit firms (those reporting positive earnings (profits) in financial statements) /loss firms (those reporting negative earnings (losses) in financial statements) and earnings managed firms (those manipulating earnings in financial statements) /non-earnings managed firms (those reporting earnings honestly without earnings management in financial statements) to observe changes in value relevance over the periods of 1994-2005. The methodology of testing the value relevance of book value, earnings and cash flows is mainly based on cross-sectional regressions of security prices on the value estimates.

The empirical results of the paper indicate that book value is the most value relevant variable and cash flows have more value relevance than earnings in all samples, subsamples and periods. The results also show that combined value relevance of book value and cash flows is more value relevant than that of book value and earnings, suggesting that cash flows can be a substitute for earnings in equity valuation model .

The rest of the paper proceeds as follows. Section 2 outlines previous related literatures that examine the value-relevance of book value, earnings and cash flows. Section 3 discusses the hypothesis and empirical models used in the study. Section 4 discusses the empirical results of the study regarding the value relevance of book value, earnings and cash flows from 1994 to 2005; While Section 5 concludes the study.

\section{Literature Review}

Since Ball and Brown (1968), and Beaver (1986) many literatures have examined the value relevance of book value, earnings and cash flows. Many studies report that book values and earnings have significant information content in equity valuation (Lev 1989; Ou and Penman 1989; Barth 1991; Easton and Harris 1991; Penman 1991; Easton, Harris and Ohlson (1992); Ou and Penman 1993; Dechow 1994; Ohlson 1995; Feltham and Ohlson 1995; Penman 1996; Barth and Kallapur 1996; Easton 1999 et.al.).

Especially, prior studies such as Rayburn (1986), Bernard and Stober (1989), Bowen et al. (1986, 1987), Livnat and Zarowin (1990), Wilson (1986, 1987), Dechow (1994), Biddle et al. (1995), Sloan (1996), Dechow et al. (1998) and Landsman and Maydew(2002) report that earnings have a higher value relevance and information content than cash flows since accrual accounting system provides a better expectation about future cash flows than does prediction about current cash receipts and payments.

For example, Livnat and Zarowin(1990) report that disaggregation of net income into operating cash flows and accruals does not have significant contributions to the stock returns beyond that of earnings. Dechow (1994) document that earnings have more ability to reflect firm performance than cash flows. Dechow et al. (1998) also finds that earnings predict expected future cash flows better than operating cash flows and the difference varies with the operating cycle. Landsman and Maydew(2002) document that the information content of earnings has not declined by examining the abnormal trading volume and abnormal return volatility.

Nevertheless, compelling literatures find that the value relevance of earnings has declined because of the sudden change in the world economic environment and firm specific characteristics (Lev 1989; Hayn 1995; Amir and Lev 1996; Basu 1997; Elliot and Hanna (1996); Collins et al. 1997; Francis and Schipper (1999); Jang et al. 2002).

Lev (1989) finds that the correlation between earnings and stock returns is very low and instable over time. Hayn (1995) finds that a much weaker relationship exists between stock returns and earnings for loss firms than for profit firms because of liquation (abandonment) options.

Basu (1997) reports that negative earnings are less persistent than positive earnings and earnings response coefficients (ERCs) are much greater for positive earnings than for negative earnings. Collins et al. (1997) also reports that much of the shift in value-relevance from earnings to book values caused by negative earnings, one-time items and changes in firm size and intangible assets across the previous forty years.

Francis and Schipper (1999) find that the value relevance of earnings has decreased over the sample period, while that of book value has increased. In Korea, Jang et al. (2002) find that although overall value relevance of book value and earnings increased over the period 1981-2000, the incremental explanatory power of earnings decrease.

Similarly, some studies indicate that earnings management to avoid losses and earnings decreases causes the deterioration of the value relevance of earnings (Degeorge Patael, Zeckhauser 1999; Burgstahler and Dichev 1997; Marquardt and Wiedman 2004). 
Furthermore, other studies document that cash flows are more value relevant than accrual earnings in predicting future cash flows because of conservative accounting effects (Wilson 1986; Bowen and Burgstahler 1986, 1987; Cheng, Liu, and Schaefer, 1997; Barth et al. 1999).

Wilson (1986) finds that cash flows and total accruals have incremental information content beyond earnings and that the total accruals has incremental information content beyond the cash flows.

Bowen and Burgstahler $(1986,1987)$ report that cash flow have incremental information content relative and in addition to that of earnings. Cheng, Liu, and Schaefer (1997) also show that estimated operating cash flows have incremental value relevance beyond earnings. Barth et al. (1999) find that accruals and cash flows provide a prediction about future abnormal earnings and book value.

\section{Hypothesis and Research Design}

\subsection{Study Hypothesis}

Although most prior literatures (Rayburn 1986; Bernard and Stober 1989; Bowen et al. 1986, 1987; Livnat and Zarowin 1990; Wilson 1986, 1987; Dechow 1994; Biddle et al. 1995; Sloan 1996; Dechow et al. 1998; Landsman and Maydew 2002) document that earnings are more value relevant than cash flows, the results are not conclusive.

On the contrary, some researches raise questions about the value relevance of earnings (Amir and Lev 1996; Basu 1997; Elliot and Hanna (1996); Francis and Schipper (1999); Jang et al. 2002). These studies document that the value relevance of earnings declined, while that of book value increased.

Similarly, other studies also indicate that earnings management and negative earnings can cause the deterioration of the value relevance of earnings (Lev 1989; Hayn 1995; Burgstahler and Dichev 1997; Collins Collins et al. 1997; Degeorge et al. 1999; Marquardt and Wiedman 2004).

Furthermore, such as Wilson (1986), Bowen and Burgstahler (1986, 1987), Cheng, Liu, and Schaefer (1997), Barth et al. (1999) find that cash flows have incremental information content consistent with earnings. Thus, following main research hypotheses emerge from the proceeding discussions of the paper.

Hypothesis 1 (H1): Book value is more value relevant than earnings and cash flows.

Hypothesis 2 (H2): The value relevance of book value, earnings and cash flows has declined.

(H2-1): When firms have negative earnings and earnings management, the value relevance of earnings decline, while that of book value and cash flows increase.

Hypothesis 3 (H3): The combined value relevance of book value and earnings decline, while that of book value and cash flows increase.

(H3-1): When firms have negative earnings and earnings management the combined value relevance of earnings and book value decline, while that of book value and cash flows increase.

The first set of hypothesis is to investigate the most value relevant factor among primary accounting variables. The second hypothesis is an extension of the first. The results of prior studies are not conclusive. Many papers (Collins et al. 1977; Lansman and Maydew, 2001) report that the value relevance of book value and earnings have not declined over time, but other studies (Francis and Schipper, 1999) document that the value relevance of earnings has declined. The last hypothesis is to examine the combined value relevance of accounting variables. Prior researches have shown that the combined value relevance of book value and earnings has declined when firms have negative earnings and earnings management (Hayn, 1995; Elliot and Hanna, 1996; Basu, 1997; Collins et al. 1997; Maydew, 1997).

\subsection{Empirical Model}

In order to examine research questions of how the book value, earnings and cash flows relate to equity value, this paper basically use a generalized version of the Ohlson (1995) model. This paper adds cash flows to the Ohlson (1995) model because the paper predicts cash flow may provide additional information about firm's equity value.

The paper test hypothesis(H1-H3) using following equations ( I, II, III, IV, V), replicating the results of Mayers (1977), Jan and Ou (1994), Ohlson (1995), and Collins et al. (1999) with Korean samples over the period 1994-2005.

The sample is segregated into several subgroups: earnings managed/ non-earnings managed firms and profit/loss firms. Several empirical literatures divide firms into profit (those reporting profits) and loss (those reporting losses) groups to investigate the reason for the shift in value relevance from earnings to book value (Hayn 1995; Collins et al. 1997; 1999; Jang et al. 2002; Kim 2003). Other papers also document that CEO's opportunistic behavior (earnings management and manipulation) may be the reason for the deterioration of accounting information's credibility and value relevance in Korean financial markets (Yoon 1998; Paek 2000; Lee and Sohn 2007). For example, Yoon (1998) documents that earnings managed firms usually have different signs of earnings and operating cash flows (the reversal signs from positive earnings to negative cash flows) in Korean financial markets. The paper replicates the result of Yoon (1998) in 
splitting total samples into earnings managed and non-earnings managed firms.

Additionally, consistent with prior studies (Kothari and Zimmerman 1995; Green, Stark and Thomas 1996; Rees 1997; Stark and Thomas 1998; Dechow, Hutton and Sloan 1999; among others), all variables are deflated total number of shares outstanding (S) to control for heteroscedasticity. Test models are presented below along with a definition of the components:

$$
\begin{aligned}
& \mathbf{P}_{\mathrm{t}}=\mathbf{b}_{1}+\mathbf{b}_{2} \mathbf{B V} \mathbf{V}_{\mathrm{t}-1} / \mathbf{S}_{\mathrm{t}}+\boldsymbol{\varepsilon}_{\mathrm{t}} \\
& \mathbf{P}_{\mathbf{t}}=\mathbf{b}_{1}+\mathbf{b}_{2} \mathbf{E}_{\mathrm{t}} / \mathbf{S}_{\mathrm{t}}+\boldsymbol{\varepsilon}_{\mathrm{t}} \\
& P_{t}=b_{1}+b_{2} C F_{t} / S_{t}+\varepsilon_{t} \\
& P_{t}=b_{1}+b_{2} E_{t} / S_{t}+b_{3} B V_{t-1} / S_{t}+\varepsilon_{t} \\
& \mathbf{P}_{\mathrm{t}}=\mathbf{b}_{1}+\mathbf{b}_{2} C F_{t} / S_{t}+b_{3} B V_{t-1} / S_{t}+\varepsilon_{t}
\end{aligned}
$$

Where:

$P_{t}$ : Stock price 3 months after the end of fiscal year $t$, where year $t$ is the event year.

$\mathrm{BV}_{\mathrm{t}-1}$ : Book value at the end of year $\mathrm{t}-1$

$\mathrm{E}_{\mathrm{t}}$ : Earnings in period $\mathrm{t}$

$\mathrm{CF}_{\mathrm{t}}$ : Operating Cash Flows in period $\mathrm{t}$

$\mathrm{S}_{\mathrm{t}}$ : Total number of shares outstanding in year $\mathrm{t}$.

$\varepsilon_{\mathrm{t}}:$ a normally distributed error term

\section{Empirical Results}

\subsection{Sample Selection and Data Source}

The paper obtains all necessary data from the KIS-FAS (Korea Investors Service-Financial Analysis System) and KISRI (Korea Securities Research Institute) stock databases. These data sets span the 12-year period from 1994 to 2005. During the process of sample selection, the study includes firms with stock prices, book values, earnings, cash flows and other financial data sufficient for empirical analysis, but the paper excludes financial banking business firms and impairment of capital firms due to administrative issues. Prior to the tests the paper eliminates outliers with Cook's Distance greater than 0.5 and absolute value of studentized residuals greater than 1 . <Table $1>$ describes the sample selection and data sources.

Insert $<$ Table $1>$ about here

4.2 Relationships among Earnings per Share, Book Value per Share, and Stock Prices

\subsubsection{Descriptive Statistics}

$<$ Table $2>$ presents descriptive statistics for the sample of stock prices per share earnings per share, book value per share, and cash flows per share. The paper identifies 7,020 firm-year observations for the period 1994-2005. Total means of $\left(\mathrm{P}_{t}\right)$ is 22,566, and its highest value is 3,600,000. Total means of $\left(E_{t} / S_{t}\right)$ is 9,747; its highest value is $5,957,381$. Total means of $\left(\mathrm{BV}_{\mathrm{t}-1} / \mathrm{S}_{\mathrm{t}}\right)$ is 28,366 ; its highest value is $1,615,159$. Total means of $\left(\mathrm{CF}_{\mathrm{t}} / \mathrm{S}_{\mathrm{t}}\right)$ is 4,382 ; its highest value is 403,751 .

Insert $<$ Table $2>$ about here

Table 3 presents the results of the correlation analysis. $\mathrm{P}_{\mathrm{t}}, \mathrm{BV}_{\mathrm{t}-1} / \mathrm{S}_{\mathrm{t}}$ and $\mathrm{CF}_{\mathrm{t}} / \mathrm{S}_{\mathrm{t}}$ are positively correlated at the $1 \%$ level, while $\mathrm{P}_{t}, \mathrm{BV}_{\mathrm{t}-1} / \mathrm{S}_{\mathrm{t}}$ and $\mathrm{E}_{\mathrm{t}} / \mathrm{S}_{\mathrm{t}}$ are not significantly correlated. These correlations suggest that $\mathrm{BV}_{\mathrm{t}-1} / \mathrm{S}_{\mathrm{t}}$ and $\mathrm{CF}_{\mathrm{t}} / \mathrm{S}_{\mathrm{t}}$ is related to $P_{t}$, but $E_{t} / S_{t}$ is not. These results are not consistent with empirical results shown in previous literatures (Hayn, 1995; Elliot and Hanna, 1996; Basu, 1997; Collins et al. 1997; Maydew, 1997; Lansman and Maydew, 2001).

Insert $<$ Table $3>$ about here

\subsubsection{Test for the Value Relevance of Book Value, Earnings and Cash Flows: Simple Linear Regression}

The paper estimates the five valuation models separately for the profit/loss firms and earnings managed/non-earnings managed firms in all year regressions. <Table $4>$ shows the value relevance of book value, earnings and cash flows using a simple linear regression models. The coefficients of $\mathrm{BV}_{\mathrm{t}-1}$ and $\mathrm{CF}_{\mathrm{t}}$ are positively significant at a level of $1 \%$ while that of earnings are not significant in all individual year regressions. The average coefficients of $\mathrm{BV}_{\mathrm{t}-1}, \mathrm{E}_{\mathrm{t}}$ and $\mathrm{CF}_{\mathrm{t}}$ are about $0.37,0.00$ and 0.98 , and the average adjusted $\mathrm{R}^{2}$ for the book value, cash flows and earnings model are about $0.37,0.24$ and 0.00 , respectively. These results show that book value and cash flows are significant value-relevant variables while earnings do not exhibit significant value relevance. The results also indicate that book value is the 
dominant value relevant factor with respect to either earnings or cash flows.

Insert $<$ Table $4>$ about here

The paper examines the value relevance of book value, earnings and operating cash flows by focusing on earnings quality (profit firms vs. loss firms) of Korean firms. Table 5 shows the value relevance of book values by dividing total samples into profit/loss firms. The coefficients of $\mathrm{BV}_{\mathrm{t}-1}$ are positively significant at a level of $1 \%$ both in profit and loss firms in all individual year regressions. The average coefficients of $\mathrm{BV}_{\mathrm{t}-1}$ are about 0.38 and 0.34 , and the average adjusted $\mathrm{R}^{2}$ are about 0.37 and 0.35 in profit/loss firms respectively. The results indicate that both in profit and loss firms, book values are significant variables of value-relevance. These results support those of Hayn (1995), Collins et al. (1997) and Han (1998), Burgstahler and Dichev (1997), Zhang (2000), who reports that the value relevance of book value.

Insert $<$ Table $5>$ about here

Table 6 reports the value relevance of earnings by dividing total samples into profit/loss firms. The coefficients of $\mathrm{E}_{\mathrm{t}} / \mathrm{S}_{\mathrm{t}}\left(\mathrm{b}_{2}\right)$ are not significant both in profit and loss firms in all individual year regressions. The average coefficients of $\mathrm{E}_{\mathrm{t}} / \mathrm{S}_{\mathrm{t}}\left(\mathrm{b}_{2}\right)$ are about 0.00 and 0.00 in profit and loss firms respectively. The results show all individual and average adjusted $\mathrm{R}^{2}$ are nearly equal to 0.00 both in profit and loss firms. These results indicate that earnings are not significant variable of value relevance both in profit and loss firms. The results are not consistent with prior literatures report that value relevance of earnings (Sloan 1996; Collins et al. 1997; Dechow et al. 1998; Landsman and Maydew 2002)

Insert $<$ Table $6>$ about here

Table 7 shows the value relevance of operating cash flows by dividing total samples into profit/loss firms. The coefficients of $\mathrm{CF}_{\mathrm{t}} / \mathrm{S}_{\mathrm{t}}\left(\mathrm{b}_{2}\right)$ are significant at a level of $1 \%$ both in profit and loss firms in all individual year regressions. The average coefficients of $\mathrm{CF}_{\mathrm{t}} / \mathrm{S}_{\mathrm{t}}\left(\mathrm{b}_{2}\right)$ in profit firms (1.04) are higher than that of loss firms (0.86). The results show average adjusted $\mathrm{R}^{2}$ in profit firms $(0.26)$ are higher than that of loss firms $(0.21)$. These results report operating cash flows are significant variable of value relevance both in profit and loss firms. Furthermore, the results suggest operating cash flows are more value relevant factor in profit firms than loss firms. These results are consistent with most recent valuation model literatures test the value relevance of cash flows (Wilson 1986; Bowen and Burgstahler 1986; 1987; Cheng, Liu, and Schaefer 1997; Barth et al. 1999).

Insert $<$ Table $7>$ about here

The paper examines the value relevance of book value, earnings and operating cash flows by focusing on opportunistic behavior (earnings managed firms vs. non-earnings managed firms) of Korean firms.

The paper basically recognizes operating cash flows as non-managed earnings and defines earnings managed groups as firms with different signs of earnings and operating cash flows (the reversal signs from positive earnings to negative cash flows). Table 8 reports the value relevance of book values by splitting the samples into earnings managed and non-earnings managed firms. The coefficients of $\mathrm{BV}_{\mathrm{t}-1} / \mathrm{S}_{\mathrm{t}}$ are significant at a level of $1 \%$ both in earnings managed firms and non-earnings managed firms in all year regressions. The average coefficients of $B V_{t-1} / S_{t}\left(b_{2}\right)$ are 0.35 in earnings managed firms and 0.37 in innocent firms respectively. The average adjusted $\mathrm{R}^{2}$ exhibit almost the same values in both groups ( 0.38 vs. 0.36$)$. The results suggest book values are significant value relevant factor regardless of opportunistic behaviors of Korean firms.

Insert $<$ Table $8>$ about here

Table 9 reports the value relevance of earnings by dividing the samples into earnings managed and non earnings managed firms. The coefficients of $E_{t} / S_{t}\left(b_{2}\right)$ are not significant in all year regressions. The average coefficients of $E_{t} / S_{t}$ $\left(b_{2}\right)$ are 0.00 in both groups and the average adjusted $R^{2}$ exhibit almost the same values in both groups $(0.00)$. The results suggest that earnings are not value relevant indicator both in earnings managed and non-earnings managed firms.

Insert $<$ Table $9>$ about here

Table 10 shows the value relevance of operating cash flows by splitting the samples into earnings managed and non-earnings managed firms. The coefficients of $\mathrm{CF}_{t} / \mathrm{S}_{\mathrm{t}}$ are significant at a level of $1 \%$ only in earnings managed firms. The average coefficients of $\mathrm{CF}_{t} / \mathrm{S}_{\mathrm{t}}\left(\mathrm{b}_{2}\right)$ are 1.09 in earnings managed firms and 0.00 in innocent firms respectively. The average adjusted $\mathrm{R}^{2}$ in earnings managed firms are much higher than that in innocent firms $(0.29>0.00)$. The results suggest operating cash flows are significant value relevant factor both in earnings managed and non-earnings managed firms.

Insert $<$ Table $10>$ about here

\subsubsection{Test for the Value Relevance of Book Value, Earnings and Cash Flows: Multiple Linear Regression}

The paper examines further incremental value relevance of main variables by combining book value, earnings and cash flows. Table 11 shows the combined value relevance of book value/earnings and book value/cash flows. In panel A of 
table 11, book values are the dominant valuation variable, while earnings are not significant in all individual year regressions. The average coefficients of $\mathrm{BV}_{\mathrm{t}-1} / \mathrm{S}_{\mathrm{t}}$ and $\mathrm{CF}_{\mathrm{t}} / \mathrm{S}_{\mathrm{t}}$ are about 0.37 and 0.00 with adjusted $\mathrm{R}^{2}$ of 0.44 . Panel $\mathrm{B}$ of table 11 shows both book value and operating cash flows are the dominant valuation variables in all individual year regressions. The average coefficients of $\mathrm{BV}_{\mathrm{t}-1} / \mathrm{S}_{\mathrm{t}}$ and $\mathrm{CF}_{t} / \mathrm{S}_{\mathrm{t}}$ are about 0.30 and 0.60 respectively with $\mathrm{R}^{2}$ value of 0.56 . By comparison, the average $\mathrm{R}^{2}$ values of the book value-cash flows model are higher than that of the book value-earnings model $(0.56$ vs. 0.44$)$. The results suggest the combined value relevance of book value and cash flows are more value relevant than that of book value and earnings model.

Insert $<$ Table $11>$ about here

Table 12 shows the combined value relevance of book value/earnings and book value/cash flows by dividing total samples into profit and loss firms. In panel A of table 12, book values are the dominant valuation variable both in profit and loss firms, while earnings are not significant valuation factor in both groups in individual year regressions. The average coefficients of $\mathrm{BV}_{\mathrm{t}-1} / \mathrm{S}_{\mathrm{t}}$ and $\mathrm{E}_{\mathrm{t}} / \mathrm{S}_{\mathrm{t}}$ are about 0.39 and 0.00 in profit firms with adjusted $\mathrm{R}^{2}$ value of 0.42 and about 0.00 and 0.34 in loss firms with adjusted $\mathrm{R}^{2}$ value of 0.49 . By comparison, the average $\mathrm{R}^{2}$ values in loss firms are higher than that in profit firms $(0.49$ vs. 0.42$)$. The results indicate that earnings have no value relevance in the combined value relevance of book value and earnings model while book value exhibit dominant value relevance regardless of earnings quality.

Insert $<$ Table $12>$ about here

Table 13 shows the combined value relevance of book value and cash flows by dividing total samples into profit and loss firms. In panel $A$ of table 13, the average coefficients of $C_{t} / S_{t}\left(b_{2}\right)$ are higher than that of $B_{t-1} / S_{t}\left(b_{3}\right)$ with adjusted R2 value of 0.62 in profit firms ( 0.63 vs. 0.30). Panel B of table 13 shows the average coefficients of $\mathrm{CF}_{t} / \mathrm{S}_{t}$ $\left(b_{2}\right)$ are higher than that of $\mathrm{BV}_{\mathrm{t}-1} / \mathrm{S}_{\mathrm{t}}\left(\mathrm{b}_{3}\right)$ with adjusted $\mathrm{R}^{2}$ value of 0.33 in loss firms. These results report the combined value relevance of book value and cash flows are more value relevant in profit firms than that in loss firms. Furthermore, cash flows have more value relevance than book value in combined value relevance of book value and cash flows model regardless of earnings quality.

Insert $<$ Table $13>$ about here

Table 14 shows the combined value relevance of book value and earnings by splitting total samples into earnings managed and non-earnings managed firms. In panel A of table 14 shows book value is more value relevant than that of earnings ( 0.35 vs. 0.01$)$ with adjusted $\mathrm{R}^{2}$ value of 0.52 . In panel $\mathrm{B}$ of table 14 , earnings have more value relevance than that of book value $(0.61$ vs. 0.30$)$ with adjusted $R^{2}$ value of 0.60 .

Insert $<$ Table $14>$ about here

These results show that book values are dominant value relevant factor in earnings managed firms, while earnings exhibit more value relevance than that of book value in innocent firms. The results also indicate that the explanatory power of combined value relevance model of earnings and book values in earnings managed firms are higher than that in non-earnings managed firms.

Table 15 shows the combined value relevance of cash flows and book value by dividing total samples into earnings managed and non-earnings managed firms. In panel A of table 15 reports cash flows is more value relevant factor than that of book values $(0.55$ vs. 0.27$)$ with adjusted $R^{2}$ value of 0.37 . In panel $B$ of table 15 , cash flows are more value relevant factor than that of book value $(0.61$ vs. 0.30$)$ with adjusted $\mathrm{R}^{2}$ value of 0.60 . By comparison, the average adjusted $\mathrm{R}^{2}$ value of the book value-cash flows model shows the explanatory power of book value-cash flows are higher in innocent firms than that in earnings managed firms. These results suggest the combined valuation model of cash flows and book value have significant value relevance regardless of opportunistic behavior of firms.

Insert $<$ Table $15>$ about here

\section{Conclusions}

This paper investigates the value relevance of book value, earnings and cash flows in the Korean stock market. This paper tests three hypotheses. First, Book value is more value relevant than earnings and cash flows. Second, the value relevance of book value, earnings and cash flows has declined. To test this hypothesis precisely, this paper examines the subhypothesis that when firms have negative earnings and earnings management, the value relevance of earnings decline, while that of book value and cash flows increase. Third, the combined value relevance of book value and earnings decline, while that of book value and cash flows increase. To examine this hypothesis, the paper test the subhypothesis that when firms have negative earnings and earnings management the combined value relevance of earnings and book value decline, while that of book value and cash flows increase.

The paper shows supportive evidence for hypothesis 1 and 3, but no supportive evidence for hypothesis 2 . This results show that book value have more value relevance than cash flows and earnings, and the combined value relevance of book value and cash flows has increased over the period 1994-2005. On the other hand, earnings show no value 
relevance, while cash flows do. Moreover, the combined value relevance of book value/cash flows has more information content beyond that of earnings/book value.

The important contribution of the study is reinvestigating the value relevance and incremental information contents of book value, earnings and cash flows. Especially the paper documents the deteriorated value relevance of earnings and the increased value relevance of cash flows in equity valuation. The results of this study are very interesting, because many prior literatures report earnings have more value relevance and incremental information content than that of cash flows. This may be just limited to the period of 1994-2005 in Korean stock markets, or this could be the true pattern in which earnings play no significant role in security prices. A following up study should extend sample period to investigate this extraordinary phenomenon of this paper.

\section{References}

Amir, E., Lev, B. (1996). Value-relevance of nonfinancial information: The wireless communications Industry. Journal of Accounting and Economics, 22, 2-30.

Ball, R. \& P. Brown. (1968). An empirical evaluation of accounting income numbers. Journal of Accounting Research, 6, 159-178.

Barth, M. (1991). Relative measurement errors among alternative pension assets and liability measures. The Accounting Review, 69, 1-25.

Barth, M.E. \& Kallapur, S. (1996). Effects of cross-sectional scale differences on regression results in empirical accounting research. Contemporary Accounting Research, 13, 527-567.

Basu, S. (1997). The conservatism principle and the asymmetric timeless of earnings. Journal of Accounting and Economics, 24, 3-37.

Beaver, W. H. (1968). The information content of annual earnings announcements. Journal of Accounting Research, 6 , 67-92.

Bernard, V. L., \& Stober, T. (1989). The nature and amount of information in cash flows and accruals. The Accounting Review, 64, 624-652.

Biddle, G., Seow, G., \& Siegel, A. (1995). Relative versus incremental information content. Contemporary Accounting Research, 12, 1-23.

Bowen, R., Burgstahler, D., \& Daley, L. (1986). Evidence on the relationships between earnings and various measures of cash flow. The Accounting Review, 61, 713-725.

Bowen, R., Burgstahler, D., \& Daley, L. (1987). The incremental information content of accrual versus cash flows. The Accounting Review, 62, 723-747.

Burgstahler, D., \& Dichev, I. (1997). Earnings management to avoid earnings decreases and losses. Journal of Accounting and Economics, 24, 99-126.

Choi, H. S., J. I. Jang, S. C. S. (2006). The relative value-relevance of earnings and cash flow measures in each life-cycle stage. Korean Management Review, 35 (5), 1339-1360, printed in Korean.

Cheng, C. S. A., Liu, C. S., \& Schaefer, T. F. (1997). The value relevance of SFAS no. 95 cash flows from operations as assessed by security market effect. Accounting Horizon, 11, 1-15.

Collins, D. W., Maydew, E., L., \& Weiss, I. S. (1997). Changes in the value-relevance of earnings and book values over the past forty years, Journal of Accounting and Economics, 24 (1), 39-67.

Dechow, P. M. (1994). Accounting earnings and cash flows as measures of firm performance: the role of accounting accruals. Journal of Accounting and Economics, 18, 3-42.

Dechow, P. M., Kothari, S. P., \& Watts, R. L. (1998). The relation between earnings and cash flows. Journal of Accounting and Economics, 25 (2), 133-166.

Dechow, P. M. A., Hutton, P., \& Sloan, R. G. (1999). An empirical assessment of the residual income valuation. Model. Journal of Accounting and Economics, 26, 1- 34.

Degeorge, F., Patael, J., \& Zeckhauser, R. (1999). Earnings management to exceed thresholds. Journal of Business, 72, $1-33$.

Easton, P. (1998). Discussion of revalued financial, tangible, and intangible assets: association with share prices and non-market-based value estimates. Journal of Accounting Research, 36 (supplement), 235-247.

Easton, P. (1999). Security returns and the value relevance of accounting data. Accounting Horizons, 13, 399-412.

Easton, P. \& Harris, T. (1991). Earnings as an explanatory variable for returns, Journal of Accounting Research, 29, 19-36. 
Easton, P.D., Harris, T.S., \& Ohlson, J. (1992). Aggregate accounting earnings can explain most of security returns. Journal of Accounting and Economics, 15, 119-142.

Elliott, J., \& Hanna, J. (1996). Repeated accounting write-offs and the information content of earnings. Journal of Accounting Research, 34 (Supplement), 135-155.

Feltham, G. \& Ohlson, J. (1995). Valuation and clean surplus accounting for operating and financial activities. Contemporary Accounting Research, 11 (2), 689-731.

Francis, J., Schipper, K., \& Vincent, L. (2002). Expanded disclosures and the increased usefulness of earnings announcements. Accounting Review, 77 (3), 515-546.

Green, J. P., Stark, A.W., \& Thomas, H. M. (1996). U.K. evidence on the market valuation of research \& development expenditures. Journal of Business Finance and Accounting, 23 (2), 191-216.

Financial Accounting Standards Board. (1983). Statement of Financial Accounting Concepts No. 1 - Objectives of Financial Reporting by Business Enterprises, Financial Accounting Standards Board, Stamford, CT.

Han, B. H. (1998). Empirical study on the deterioration of accruals management. Korean Accounting Research, 23 (4), 53-79, printed in Korean.

Hand, J. \& Landsman, W. (1999). The pricing of dividends in equity valuation, Working Paper, University of North Carolina, Chapel Hill.

Hayn, C. (1995). The information contents of losses. Journal of Accounting and Economics, 20 (September), 125-153.

Jang, J. I., Jung, H. J., \& Lee, K. J. (2002). The value relevance of accounting earnings and book value,. Daehan Journal of Business, December, 513-533, printed in Korean.

Kim, B. H. (2003). Information content of firms losses in korean stock markets: empirical analyses based on the firm liquidation option hypothesis and the earnings mean-reversion hypothesis. Journal of Korean Securities, 32, 191-221, printed in Korean

Landsman, W. \& Maydew, A. (2002). Has the information content of quarterly earnings Announcements declined in the past three decades? Journal of Accounting Research, 40 (3), 797-808.

Lee, E. C., Sohn, S. K. (2007). A second look at earning management to avoid loss: based on cross-sectional histogram using discretionary accruals. Korean Accounting Review, 32 (2), 61-87, printed in Korean.

Lev, B. (1989). On the usefulness of earnings and earnings research: lessons and directions from two decades of empirical research. Journal of Accounting Research, 27 (Supplement), 153-192.

Barth, M. E., Beaver, J. R. M., Hand, R. M., \& Landsman, W. R. (1999). Accruals, cash flows, and equity values. Review of Accounting Studies, 4, (3-4), 205-229.

Maydew, E. (1993). Tax-induced earnings management by firms with net operating losses. Journal of Accounting Research, 35, 83-96.

Marquardt, C. A., \& Christine I. W. (2004). The effect of earnings management on the value relevance of accounting information. Journal of Business Finance and Accounting, 31 (3-4), 297-332.

Kothari, S. P. \& Zimmerman, J. L. (1995). Price and return models. Journal of Accounting and Economics, 20, 155-192.

Livnat, J. \& Zarowin, P. (1990). The incremental information content of cash-flow components. Journal of Accounting and Economics, 13, 25-46.

Myers. S. C. (1977). Determinants of corporate borrowing. Journal of financial Economics, 5, 147-175.

Ohlson, J. A. (1995). Earnings, book values and dividends in equity valuation. Contemporary Accounting Research, 11, 661-87.

Ou, J. A. \& Penman, S. H. (1993). Fundamental statement analysis and the evaluation of market-to-book ratio, Working Paper. Santa Clara, CA: Santa Clara University.

Paek, W, S. (2000). The comparison of discretionary accruals estimates: using modified Jones model. Korean Accounting Review, 25 (3), 29-55, printed in Korean.

Penman, S. (1991). An evaluation of accounting rate of return. Journal of Accounting, Auditing and Finance, 2, 233-256.

Penman, S. (1996). The articulation of price-earnings ratios and market-to-book ratios and the evaluation of growth. Journal of Accounting Research, 34, 235-259.

Rayburn, J. (1986). The association of operating cash flow and accruals with security returns. Journal of Accounting Research, 24 (Supplement), 112-133. 
Sloan, R. G. (1996). Do stock prices fully reflect information in accruals and cash flows about future earnings. The Accounting Review, 71, 289-316.

Stark, A.W., \& Thomas, H. M. (1998). On the empirical relationship between market value and residual income in the U.K. Management Accounting Research, 9 (4), 445-460.

Wilson, P. (1986). The relative information content of accruals and cash flows: combined evidence at the earnings announcement and annual report release date. Journal of Accounting Research, 24 (Supplement), 165-200.

Yee, K. (2000). Opportunities knocking: residual income valuation of an adaptive firm. Journal of Accounting, Auditing and Finance, 15 (3), 225-266.

Yoon, S. S. (1998). Empirical Analysis on Earnings Management According to Operating Cash Flows. Korean Accounting Review, 23 (1), 107-126. printed in Korean.

Zhang, G. (2000). Accounting information, capital investment decision, and equity valuation: theory and empirical implications. Journal of Accounting Research, 38 (2), 271-295.

Table 1. Sample selection

\begin{tabular}{|c|c|}
\hline Total firm-year observations from 1994 to 2005 & 7,020 \\
\hline (-) Firms missing annual data from 1994 to 2005 & 1,950 \\
\hline (-) Impairment of capital firms annually from 1994 to 2005 & 205 \\
\hline = Total number of analysis data & 4,865 \\
\hline
\end{tabular}

Table 2. Descriptive statistics

\begin{tabular}{|c|c|c|c|c|}
\hline Variable & Mean & $\begin{array}{c}\text { Standard } \\
\text { deviation }\end{array}$ & Minimum & Maximum \\
\hline $\mathrm{P}_{\mathrm{t}}$ & 22,566 & 68,116 & 75 & $3,600,000$ \\
\hline $\mathrm{E}_{\mathrm{t}} / \mathrm{S}_{\mathrm{t}}$ & 9,747 & 142,094 & $-2,447,856$ & $5,957,381$ \\
\hline $\mathrm{BV}_{\mathrm{t}-1} / \mathrm{S}_{\mathrm{t}}$ & 28,366 & 66,599 & 1.4 & $1,615,159$ \\
\hline $\mathrm{CF}_{\mathrm{t}} / \mathrm{S}_{\mathrm{t}}$ & 4,382 & 20,458 & $-941,565$ & 403,751 \\
\hline
\end{tabular}

Variable definitions: $\mathrm{P}_{\mathrm{t}}=$ Stock price 3 months after the end of fiscal year $\mathrm{t}$, where year $\mathrm{t}$ is the event year; $\mathrm{BV} t-1=\mathrm{Book}$ value at the end of year $\mathrm{t}-1 ; \mathrm{E}_{\mathrm{t}}=$ Earnings in period $\mathrm{t} ; \mathrm{CF}_{\mathrm{t}}=$ Operating Cash Flows in period $\mathrm{t}$; $\mathrm{S}_{\mathrm{t}}=$ Total number of shares outstanding in year $\mathrm{t}$.

Table 3. Correlation analysis of the variables

\begin{tabular}{|c|c|c|c|c|}
\hline & $\mathrm{P}_{\mathrm{t}}$ & $\mathrm{E}_{\mathrm{t}} / \mathrm{S}_{\mathrm{t}}$ & $\mathrm{BV}_{\mathrm{t}-1} / \mathrm{S}_{\mathrm{t}}$ & $\mathrm{CF}_{\mathrm{t}} / \mathrm{S}_{\mathrm{t}}$ \\
\hline \multirow{2}{*}{$\mathrm{P}_{\mathrm{t}}$} & 1.00 & 0.00 & 0.41 & 0.35 \\
\cline { 2 - 5 } & & 0.96 & $<.0001$ & $<.0001$ \\
\hline \multirow{2}{*}{$\mathrm{E}_{\mathrm{t}} / \mathrm{S}_{\mathrm{t}}$} & 0.00 & 1.00 & 0.00 & 0.01 \\
\cline { 2 - 5 } & 0.96 & & 0.79 & 0.30 \\
\hline \multirow{2}{*}{$\mathrm{BV}_{\mathrm{t}-1} / \mathrm{S}_{\mathrm{t}}$} & 0.41 & 0.00 & 1.00 & 0.42 \\
\cline { 2 - 5 } & $<.0001$ & 0.79 & & $<.0001$ \\
\hline \multirow{2}{*}{$\mathrm{CF}_{\mathrm{t}} / \mathrm{S}_{\mathrm{t}}$} & 0.35 & 0.01 & 0.42 & 1.00 \\
\cline { 2 - 5 } & $<.0001$ & 0.30 & $<.0001$ & \\
\hline
\end{tabular}

Pearson's coefficient of correlation, two-sided test, Variable definitions: refer to $<$ Table $2>$ 
Table 4. Simple Linear Regression of Stock prices on Book Value, Earnings and Cash Flows

\begin{tabular}{|c|c|c|c|c|c|c|c|c|c|}
\hline \multirow{2}{*}{ Year } & \multicolumn{3}{|c|}{ (A) $\mathrm{P}_{\mathrm{t}}=\mathrm{b}_{1}+\mathrm{b}_{2} \mathrm{BV}_{\mathrm{t}-\mathrm{l}} / \mathrm{S}_{\mathrm{t}}+\varepsilon$} & \multicolumn{3}{|c|}{ (B) $\mathrm{P}_{\mathrm{t}}=\mathrm{b}_{1}+\mathrm{b}_{2} \mathrm{E}_{\mathrm{t}} / \mathrm{S}_{\mathrm{t}}+\varepsilon$} & \multicolumn{3}{|c|}{ (C) $\mathrm{P}_{\mathrm{t}}=\mathrm{b}_{1}+\mathrm{b}_{2} \mathrm{CF}_{\mathrm{t}} / \mathrm{S}_{\mathrm{t}}+\varepsilon$} \\
\hline & $\operatorname{Adj} R^{2}$ & $\mathrm{~b} 1$ & b2 & $\operatorname{Adj} R^{2}$ & b1 & b2 & $\operatorname{Adj~} R^{2}$ & b1 & b2 \\
\hline 2005 & 0.51 & $3679.49 * *$ & $0.47 * *$ & 0 & $14192 * *$ & -0.01 & 0.49 & $7447.64 * *$ & $2.84 * *$ \\
\hline 2004 & 0.42 & $3436.18^{* *}$ & $0.31 * *$ & 0 & $10608 * *$ & -0.01 & 0.72 & $4542.80 * *$ & $2.29 * *$ \\
\hline 2003 & 0.49 & $2635.48 * *$ & $0.22 * *$ & 0 & $7745.55^{* *}$ & 0 & 0.65 & $2839.13 * *$ & $1.78^{* *}$ \\
\hline 2002 & 0.39 & $6660.78 * *$ & $0.28 * *$ & 0 & $12912 * *$ & 0 & 0.12 & $10262 * *$ & $0.70 * *$ \\
\hline 2001 & 0.49 & $3727.82 * *$ & $0.19^{* *}$ & 0.01 & $8057.10^{* *}$ & 0 & 0.19 & $6013.49 * *$ & $0.65^{* *}$ \\
\hline 2000 & 0.21 & $9081.36^{* *}$ & $0.22 * *$ & 0.01 & $11991 * *$ & 0 & 0.61 & $7400.17 * *$ & $2.49 * *$ \\
\hline 1999 & 0.37 & $9815.07 * *$ & $0.27 * *$ & 0 & $13922 * *$ & 0 & 0.78 & $9873.52 * *$ & $1.31 * *$ \\
\hline 1998 & 0.52 & $1146.70 * *$ & $0.69 * *$ & 0 & $13356^{* *}$ & 0 & 0.8 & $10188 * *$ & $1.01 * *$ \\
\hline 1997 & 0.81 & $7371.21 * *$ & $0.79 * *$ & 0 & $22405 * *$ & 0.04 & 0.36 & $20389 * *$ & $1.34 * *$ \\
\hline 1996 & 0.59 & $6168.80 * *$ & $0.74 * *$ & 0.01 & $19318 * *$ & 0.04 & 0.42 & $15965^{* *}$ & $1.64 * *$ \\
\hline 1995 & 0.62 & $7521.85^{* *}$ & $1.00 * *$ & 0 & $25052 * *$ & 0.02 & 0.35 & $22204 * *$ & $1.62 * *$ \\
\hline 1994 & 0.61 & $9475.39 * *$ & $0.66^{* *}$ & 0 & $20405 * *$ & 0.01 & 0.46 & $17514 * *$ & $1.26 * *$ \\
\hline 1994-2005 & 0.37 & $8231.84 * *$ & $0.37 * *$ & 0 & $14770 * *$ & 0 & 0.24 & $13339 * *$ & $0.98 * *$ \\
\hline
\end{tabular}

Variable definitions: refer to <Table $2>, *(* *)$ : Significant at the .05 (.01) level.

Table 5. Simple Linear Regression of Stock prices on Book Value for Profit firms and Loss firms, Respectively

\begin{tabular}{|c|c|c|c|c|c|c|}
\hline \multirow{3}{*}{ Year } & \multicolumn{6}{|c|}{$\mathrm{P}_{\mathrm{t}}=\mathrm{b}_{1}+\mathrm{b}_{2} \mathrm{BV}_{\mathrm{t}-1} / \mathrm{S}_{\mathrm{t}}+\varepsilon$} \\
\hline & \multicolumn{3}{|c|}{ (A) Profit Firms } & \multicolumn{3}{|c|}{ Loss Firms } \\
\hline & $\operatorname{Adj} R^{2}$ & b1 & $\mathrm{b} 2$ & $\operatorname{Adj} R^{2}$ & $\mathrm{~b} 1$ & $\mathrm{~b} 2$ \\
\hline 2005 & 0.51 & $3908.40 * *$ & $0.46^{* *}$ & 0.52 & 2733.9 & $0.50 * *$ \\
\hline 2004 & 0.47 & $3167.83 * *$ & $0.31 * *$ & 0.29 & $4493.01 *$ & $0.32 * *$ \\
\hline 2003 & 0.49 & $2694.52 * *$ & $0.22 * *$ & 0.52 & $2360.29 * *$ & $0.22 * *$ \\
\hline 2002 & 0.36 & $6637.54 * *$ & $0.26^{* *}$ & 0.45 & $7207.95 * *$ & $0.31 * *$ \\
\hline 2001 & 0.44 & $3806.15^{* *}$ & $0.18^{* *}$ & 0.58 & $3640.33 * *$ & $0.21 * *$ \\
\hline 2000 & 0.19 & $8968.40 * *$ & $0.21 * *$ & 0.27 & $9384.73 * *$ & $0.22 * *$ \\
\hline 1999 & 0.42 & $8514.48^{* *}$ & $0.31 * *$ & 0.29 & $12733 * *$ & $0.20 * *$ \\
\hline 1998 & 0.52 & 1141.14 & $0.70^{* *}$ & 0.52 & 1145.1 & $0.68^{* *}$ \\
\hline 1997 & 0.87 & $6526.54 * *$ & $0.79 * *$ & 0.45 & $8753.74 * *$ & $0.80 * *$ \\
\hline 1996 & 0.58 & $6650.23 * *$ & $0.72 * *$ & 0.62 & $5008.56^{* *}$ & $0.81 * *$ \\
\hline 1995 & 0.56 & $7782.42 * *$ & $0.98^{* *}$ & 0.76 & $7069.61 * *$ & $1.02 * *$ \\
\hline 1994 & 0.6 & $9808.07 * *$ & $0.65^{* *}$ & 0.64 & $8478.70 * *$ & $0.68^{* *}$ \\
\hline $1994-2005$ & 0.37 & $7649.43 * *$ & $0.38^{* *}$ & 0.35 & $9813.33^{* *}$ & $0.34 * *$ \\
\hline
\end{tabular}

Variable definitions: refer to $<$ Table $2>{ }^{*}(* *)$ : Significant at the $.05(.01)$ level. 
Table 6. Simple Linear Regression of Stock prices on Earnings for Profit firms and Loss firms, Respectively

\begin{tabular}{|c|c|c|c|c|c|c|}
\hline \multirow{2}{*}{ Year } & \multicolumn{5}{|c|}{$\mathrm{P}_{\mathrm{t}}=\mathrm{b}_{1}+\mathrm{b}_{2} \mathrm{E}_{\mathrm{t}} / \mathrm{S}_{\mathrm{t}}+\varepsilon$} \\
\cline { 2 - 7 } & \multicolumn{3}{|c|}{ (A) Profit Firms } & \multicolumn{3}{c|}{ (B) Loss Firms } \\
\cline { 2 - 7 } & Adj $\mathrm{R}^{2}$ & $\mathrm{~b} 1$ & $\mathrm{~b} 2$ & Adj $\mathrm{R}^{2}$ & $\mathrm{~b} 1$ & $\mathrm{~b} 2$ \\
\hline 2005 & 0 & $14169^{* *}$ & -0.01 & 0 & $13520^{* *}$ & -0.23 \\
\hline 2004 & 0 & $10062^{* *}$ & -0.01 & -0.01 & $13353^{* *}$ & 0.12 \\
\hline 2003 & 0 & $7620.31^{* *}$ & 0 & -0.02 & $8491.65^{* *}$ & 0.01 \\
\hline 2002 & 0 & $12624^{* *}$ & 0.01 & -0.01 & $13738^{* *}$ & 0 \\
\hline 2001 & 0.03 & $7356.34^{* *}$ & $0.01^{* *}$ & 0.01 & $9523.10^{* *}$ & -0.01 \\
\hline 2000 & 0.01 & $11157^{* *}$ & $0.00^{*}$ & -0.01 & $14646^{* *}$ & 0.01 \\
\hline 1999 & 0 & $13690^{* *}$ & -0.01 & 0.01 & $16114^{* *}$ & 0.01 \\
\hline 1998 & 0 & $12742^{* *}$ & 0.01 & -0.01 & $14674^{* *}$ & 0.01 \\
\hline 1997 & 0.02 & $21413^{* *}$ & $0.11^{*}$ & -0.01 & $23602^{* *}$ & 0 \\
\hline 1996 & 0.01 & $19124^{* *}$ & 0.06 & -0.01 & $19263^{* *}$ & 0.02 \\
\hline 1995 & 0.01 & $24333^{* *}$ & 0.05 & 0 & $27245^{* *}$ & -0.06 \\
\hline 1994 & 0 & $20298^{* *}$ & 0.01 & -0.02 & $20416^{* *}$ & -0.04 \\
\hline $1994-2005$ & 0 & $14360^{* *}$ & $0.00^{*}$ & 0 & 16314 & 0 \\
\hline
\end{tabular}

Variable definitions: refer to <Table 2>, * (**): Significant at the .05 (.01) level.

Table 7. Simple Linear Regression of Stock prices on Cash Flows for Profit Firms and Loss Firms, Respectively

\begin{tabular}{|c|c|c|c|c|c|c|}
\hline \multirow{2}{*}{ Year } & \multicolumn{5}{|c|}{$\mathrm{P}_{\mathrm{t}}=\mathrm{b}_{1}+\mathrm{b}_{2} \mathrm{CF}_{\mathrm{t}} / \mathrm{S}_{\mathrm{t}}+\varepsilon$} \\
\cline { 2 - 7 } & \multicolumn{3}{|c}{ (A) Profit Firms } & \multicolumn{3}{c|}{ (B) Loss Firms } \\
\cline { 2 - 7 } & Adj $\mathrm{R}^{2}$ & $\mathrm{~b} 1$ & $\mathrm{~b} 2$ & Adj $\mathrm{R}^{2}$ & $\mathrm{~b} 1$ & $\mathrm{~b} 2$ \\
\hline 2005 & 0.42 & $7856.48^{* *}$ & $2.58^{* *}$ & 0.67 & $6272.72^{* *}$ & $3.47^{* *}$ \\
\hline 2004 & 0.75 & $4659.19^{* *}$ & $2.33^{* *}$ & 0.39 & $5001.91^{* *}$ & $1.87^{* *}$ \\
\hline 2003 & 0.67 & $2740.04^{* *}$ & $1.79^{* *}$ & 0.4 & $3375.92^{* *}$ & $1.66^{* *}$ \\
\hline 2002 & 0.16 & $9776.38^{* *}$ & $0.81^{* *}$ & 0.05 & $11811^{* *}$ & $0.44^{*}$ \\
\hline 2001 & 0.19 & $5883.42^{* *}$ & $0.62^{* *}$ & 0.2 & $6217.78^{* *}$ & $0.78^{* *}$ \\
\hline 2000 & 0.68 & $6673.99^{* *}$ & $2.68^{* *}$ & 0.08 & $13427^{* *}$ & $0.81^{* *}$ \\
\hline 1999 & 0.83 & $9241.43^{* *}$ & $1.33^{* *}$ & 0.22 & $13273^{* *}$ & $0.91^{* *}$ \\
\hline 1998 & 0.87 & $9956.70^{* *}$ & $1.04^{* *}$ & 0.42 & $11394^{* *}$ & $0.76^{* *}$ \\
\hline 1997 & 0.36 & $20184^{* *}$ & $1.28^{* *}$ & 0.36 & $20681^{* *}$ & $1.48^{* *}$ \\
\hline 1996 & 0.45 & $15742^{* *}$ & $1.72^{* *}$ & 0.33 & $16424^{* *}$ & $1.44^{* *}$ \\
\hline 1995 & 0.31 & $22170^{* *}$ & $1.47^{* *}$ & 0.47 & $22593^{* *}$ & $1.98^{* *}$ \\
\hline 1994 & 0.51 & $17658^{* *}$ & $1.33^{* *}$ & 0.27 & $17149^{* *}$ & $0.94^{* *}$ \\
\hline $1994-2005$ & 0.26 & $12763^{* *}$ & $1.04^{* *}$ & 0.21 & $14907^{* *}$ & $0.86^{* *}$ \\
\hline
\end{tabular}

Variable definitions: refer to <Table $2>,{ }^{*}(*)$ : Significant at the $.05(.01)$ level. 
Table 8. Simple Linear Regression of Stock prices on Book Value for Earnings Managed Firms and Non-Earnings Managed Firms, Respectively

\begin{tabular}{|c|c|c|c|c|c|c|}
\hline \multirow{3}{*}{ Year } & \multicolumn{6}{|c|}{$\mathrm{P}_{\mathrm{t}}=\mathrm{b}_{1}+\mathrm{b}_{2} \mathrm{BV}_{\mathrm{t}-1} / \mathrm{S}_{\mathrm{t}}+\varepsilon$} \\
\hline & \multicolumn{2}{|c|}{ (A) Earn } & irms & \multicolumn{3}{|c|}{ (B) Non-Earnings Managed Firms } \\
\hline & Adj $R^{2}$ & b1 & b2 & Adj $R^{2}$ & b1 & b2 \\
\hline 2005 & 0.56 & $1,065.21$ & $0.64 * *$ & 0.51 & $4000.79 * *$ & $0.44 * *$ \\
\hline 2004 & 0.28 & $5395.58 *$ & $0.34 * *$ & 0.46 & $3054.43 * *$ & $0.31 * *$ \\
\hline 2003 & 0.38 & $1,675.92$ & $0.28 * *$ & 0.51 & $2648.65^{* *}$ & $0.21 * *$ \\
\hline 2002 & 0.45 & $7595.77 * *$ & $0.31 * *$ & 0.36 & $6584.26^{* *}$ & $0.26 * *$ \\
\hline 2001 & 0.58 & $3957.55 * *$ & $0.20 * *$ & 0.45 & $3707.27 * *$ & $0.18^{* *}$ \\
\hline 2000 & 0.27 & $9983.29 * *$ & $0.22 * *$ & 0.19 & $8889.43 * *$ & $0.21 * *$ \\
\hline 1999 & 0.33 & $12922 * *$ & $0.20 * *$ & 0.4 & $8652.93 * *$ & $0.31 * *$ \\
\hline 1998 & 0.52 & $1,765.06$ & $0.68 * *$ & 0.52 & 936.77 & $0.69 * *$ \\
\hline 1997 & 0.49 & $8742.70 * *$ & $0.85 * *$ & 0.85 & $6691.28 * *$ & $0.79 * *$ \\
\hline 1996 & 0.69 & $4461.05 * *$ & $0.86^{* *}$ & 0.56 & $6607.58 * *$ & $0.71 * *$ \\
\hline 1995 & 0.8 & $7705.66^{* *}$ & $1.03 * *$ & 0.55 & $7728.28 * *$ & $0.97 * *$ \\
\hline 1994 & 0.68 & $8379.24 * *$ & $0.70 * *$ & 0.59 & $9726.84 * *$ & $0.64 * *$ \\
\hline 1994-2005 & 0.38 & $9895.83 * *$ & $0.35 * *$ & 0.36 & $7833.31 * *$ & $0.37 * *$ \\
\hline
\end{tabular}

Variable definitions: refer to <Table 2>, * (**): Significant at the .05 (.01) level.

Table 9. Simple Linear Regression of Stock prices on Earnings for Earnings Managed firms and Non-Earnings managed firms, Respectively

\begin{tabular}{|c|c|c|c|c|c|c|}
\hline \multirow{2}{*}{ Year } & \multicolumn{6}{|c|}{$\mathrm{P}_{\mathrm{t}}=\mathrm{b}_{1}+\mathrm{b}_{2} \mathrm{E}_{\mathrm{t}} / \mathrm{S}_{\mathrm{t}}+\varepsilon$} \\
\cline { 2 - 7 } & \multicolumn{2}{|c|}{ (A) } & \multicolumn{6}{|c|}{ Earnings Managed Firms } & \multicolumn{2}{c|}{$(\mathrm{B})$} & \multicolumn{2}{c|}{ Non-Earnings Managed Firms } \\
\cline { 2 - 7 } & Adj $\mathrm{R}^{2}$ & $\mathrm{~b} 1$ & $\mathrm{~b} 2$ & $\mathrm{Adj} \mathrm{R}^{2}$ & $\mathrm{~b} 1$ & $\mathrm{~b} 2$ \\
\hline 2005 & -0.02 & $15796^{* *}$ & 0.12 & 0 & $14005^{* *}$ & -0.01 \\
\hline 2004 & -0.01 & $15262^{* *}$ & 0.15 & 0 & $9840.92^{* *}$ & -0.01 \\
\hline 2003 & -0.01 & $7927.64^{* *}$ & -0.06 & 0 & $7685.29^{* *}$ & 0 \\
\hline 2002 & -0.02 & $14652^{* *}$ & 0 & 0 & $12517^{* *}$ & 0.01 \\
\hline 2001 & -0.01 & $9820.70^{* *}$ & -0.01 & 0.02 & $7561.56^{* *}$ & $0.01^{*}$ \\
\hline 2000 & -0.01 & $15763^{* *}$ & 0 & 0.01 & $11204^{* *}$ & $0.00^{*}$ \\
\hline 1999 & 0 & $16650^{* *}$ & 0.01 & 0 & $13510^{* *}$ & 0 \\
\hline 1998 & -0.01 & $16340^{* *}$ & 0.01 & 0 & $12406^{* *}$ & 0.02 \\
\hline 1997 & -0.01 & $25769^{* *}$ & 0.03 & 0.01 & $21622^{* *}$ & 0.08 \\
\hline 1996 & 0 & $20152^{* *}$ & 0.02 & 0.01 & $18973^{* *}$ & $0.06^{*}$ \\
\hline 1995 & -0.03 & $27931^{* *}$ & -0.13 & 0 & $24631^{* *}$ & 0.03 \\
\hline 1994 & -0.03 & $20761^{* *}$ & -0.04 & 0 & $20280^{* *}$ & 0.02 \\
\hline $1994-2005$ & 0 & $17090^{* *}$ & 0 & 0 & $14347^{* *}$ & $0.00^{*}$ \\
\hline
\end{tabular}

Variable definitions: refer to $<$ Table $2>,{ }^{*}(*)$ : Significant at the $.05(.01)$ level. 
Table 10. Simple Linear Regression of Stock prices on Cash Flows for Earnings Managed firms and Non-Earnings Managed firms, Respectively

\begin{tabular}{|c|c|c|c|c|c|c|}
\hline \multirow{3}{*}{ Year } & \multicolumn{6}{|c|}{$\mathrm{P}_{\mathrm{t}}=\mathrm{b}_{1}+\mathrm{b}_{2} \mathrm{CF}_{\mathrm{t}} / \mathrm{S}_{\mathrm{t}}+\varepsilon$} \\
\hline & \multirow{2}{*}{$\frac{(\mathrm{A})}{\operatorname{Adj} \mathrm{R}^{2}}$} & \multicolumn{2}{|c|}{ Earnings Managed Firms } & \multicolumn{3}{|c|}{ Non-Earnings Managed Firms } \\
\hline & & b1 & b2 & $\operatorname{Adj} R^{2}$ & b1 & b2 \\
\hline 2005 & 0.71 & $4770.99 *$ & $3.64 * *$ & 0 & $14005 * *$ & -0.01 \\
\hline 2004 & 0.36 & $5073.04 * *$ & $1.88^{* *}$ & 0 & $9840.92 * *$ & -0.01 \\
\hline 2003 & 0.45 & $2185.96^{*}$ & $2.03 * *$ & 0 & $7685.29 * *$ & 0 \\
\hline 2002 & 0.04 & $12356^{* *}$ & $0.42 *$ & 0 & $12517 * *$ & 0.01 \\
\hline 2001 & 0.21 & $5363.70^{* *}$ & $0.91 * *$ & 0.02 & $7561.56^{* *}$ & $0.00 *$ \\
\hline 2000 & 0.08 & $12439 * *$ & $0.96^{* *}$ & 0.01 & $11204 * *$ & $0.00 *$ \\
\hline 1999 & 0.27 & $10124 * *$ & $1.24 * *$ & 0 & $13510^{* *}$ & 0 \\
\hline 1998 & 0.48 & $9337.85^{* *}$ & $0.90 * *$ & 0 & $12406 * *$ & 0.02 \\
\hline 1997 & 0.42 & $16771^{* *}$ & $1.98 * *$ & 0.01 & $21622 * *$ & 0.08 \\
\hline 1996 & 0.46 & $10653 * *$ & $2.46^{* *}$ & 0.01 & $18973 * *$ & $0.06^{*}$ \\
\hline 1995 & 0.54 & $18860 * *$ & $2.51 * *$ & 0 & $24631 * *$ & 0.03 \\
\hline 1994 & 0.24 & $15725^{* *}$ & $1.17^{* *}$ & 0 & $20280 * *$ & 0.02 \\
\hline 1994-2005 & 0.29 & $12510 * *$ & $1.09 * *$ & 0 & $14347 * *$ & $0.00 *$ \\
\hline
\end{tabular}

Variable definitions: refer to <Table 2>, * (**): Significant at the $.05(.01)$ level.

Table 11. Multiple Linear Regression of Stock prices on Earnings/Book Value and Cash Flows/Book Value

\begin{tabular}{|c|c|c|c|c|c|c|c|c|}
\hline \multirow{2}{*}{ Year } & \multicolumn{2}{|c}{$(\mathrm{A})$} & $\mathrm{P}_{\mathrm{t}}=\mathrm{b}_{1}+\mathrm{b}_{2} \mathrm{E}_{\mathrm{t}} / \mathrm{S}_{\mathrm{t}}+\mathrm{b} 3 \mathrm{BV} \mathrm{V}_{\mathrm{t}-1} / \mathrm{S}_{\mathrm{t}}+\varepsilon_{\mathrm{t}}$ & \multicolumn{2}{c|}{$(\mathrm{B})$} & $\mathrm{P}_{\mathrm{t}}=\mathrm{b}_{1}+\mathrm{b}_{2} \mathrm{CF}_{\mathrm{t}} / \mathrm{S}_{\mathrm{t}}+\mathrm{b} 3 \mathrm{BV} \mathrm{V}_{\mathrm{t}-1} / \mathrm{S}_{\mathrm{t}}+\varepsilon_{\mathrm{t}}$ \\
\cline { 2 - 10 } & Adj $\mathrm{R}^{2}$ & $\mathrm{~b} 1$ & $\mathrm{~b} 2$ & $\mathrm{~b} 3$ & $\mathrm{Adj} \mathrm{R}^{2}$ & $\mathrm{~b} 1$ & $\mathrm{~b} 2$ & $\mathrm{~b} 3$ \\
\hline 2005 & 0.52 & $3917.50^{* *}$ & $-0.03^{*}$ & $0.47^{* *}$ & 0.72 & $2368.84^{* *}$ & $1.33^{* *}$ & $0.40^{* *}$ \\
\hline 2004 & 0.43 & $3498.63^{* *}$ & -0.01 & $0.31^{* *}$ & 0.75 & $2524.27^{* *}$ & $1.54^{* *}$ & $0.17^{* *}$ \\
\hline 2003 & 0.5 & $2675.14^{* *}$ & 0 & $0.22^{* *}$ & 0.69 & $1936.94^{* *}$ & $1.42^{* *}$ & $0.085^{* *}$ \\
\hline 2002 & 0.4 & $6507.30^{* *}$ & 0 & $0.28^{* *}$ & 0.43 & $5950.33^{* *}$ & $0.38^{* *}$ & $0.26^{* *}$ \\
\hline 2001 & 0.52 & $3688.71^{* *}$ & 0 & $0.19^{* *}$ & 0.5 & $3637.46^{* *}$ & $0.15^{* *}$ & $0.17^{* *}$ \\
\hline 2000 & 0.52 & $5793.81^{* *}$ & 0 & $0.25^{* *}$ & 0.66 & $4239.49^{* *}$ & $1.69^{* *}$ & $0.22^{* *}$ \\
\hline 1999 & 0.46 & $8405.98^{* *}$ & $0.00^{*}$ & $0.26^{* *}$ & 0.39 & $9109.86^{* *}$ & $0.61^{* *}$ & $0.169^{* *}$ \\
\hline 1998 & 0.48 & $2397.48^{* *}$ & 0.02 & $0.61^{* *}$ & 0.56 & $2646.72^{* *}$ & $0.38^{* *}$ & $0.51^{* *}$ \\
\hline 1997 & 0.57 & $8212.14^{* *}$ & -0.01 & $0.70^{* *}$ & 0.62 & $11659^{* *}$ & $0.84^{* *}$ & $0.48^{* *}$ \\
\hline 1996 & 0.72 & $5309.68^{* *}$ & 0 & $0.71^{* *}$ & 0.72 & $7219.54^{* *}$ & $0.95^{* *}$ & $0.51^{* *}$ \\
\hline 1995 & 0.7 & $7048.85^{* *}$ & -0.02 & $0.99^{* *}$ & 0.67 & $7027.38^{* *}$ & $0.80^{* *}$ & $0.95^{* *}$ \\
\hline 1994 & 0.73 & $8684.89^{* *}$ & $0.01^{*}$ & $0.70^{* *}$ & 0.68 & $10195^{* *}$ & $0.58^{* *}$ & $0.55^{* *}$ \\
\hline $1994-2005$ & 0.44 & $6658.46^{* *}$ & 0 & $0.37^{* *}$ & 0.56 & $7868.27^{* *}$ & $0.60^{* *}$ & $0.30^{* *}$ \\
\hline
\end{tabular}

Variable definitions: refer to $<$ Table $2>, *(* *)$ : Significant at the $.05(.01)$ level. 
Table 12. Multiple Linear Regression of Stock prices on Earnings/Book Value for Profit firms and Loss firms, Respectively

\begin{tabular}{|c|c|c|c|c|c|c|c|c|}
\hline \multirow{2}{*}{ Year } & \multicolumn{7}{|c|}{$\mathrm{P}_{\mathrm{t}}=\mathrm{b}_{1}+\mathrm{b}_{2} \mathrm{E}_{\mathrm{t}} / \mathrm{S}_{\mathrm{t}}+\mathrm{b} 3 \mathrm{BV} \mathrm{V}_{\mathrm{t}-1} / \mathrm{S}_{\mathrm{t}}+\varepsilon_{\mathrm{t}}$} \\
\cline { 2 - 9 } & \multicolumn{3}{|c|}{ (A) Profit Firms } & \multicolumn{3}{|c|}{ (B) Loss Firms } \\
\cline { 2 - 10 } & Adj $\mathrm{R}^{2}$ & $\mathrm{~b} 1$ & $\mathrm{~b} 2$ & $\mathrm{~b} 3$ & Adj $\mathrm{R}^{2}$ & $\mathrm{~b} 1$ & $\mathrm{~b} 2$ & $\mathrm{~b} 3$ \\
\hline 2005 & 0.51 & $4296.36^{* *}$ & $(-) 0.04^{*}$ & $0.46^{* *}$ & 0.58 & $2618.94^{* *}$ & 0.36 & $0.55^{* *}$ \\
\hline 2004 & 0.47 & $3327.58^{* *}$ & -0.01 & $0.31^{* *}$ & 0.32 & $4949.79^{*}$ & 0.37 & $0.34^{* *}$ \\
\hline 2003 & 0.49 & $2719.69^{* *}$ & 0 & $0.22^{* *}$ & 0.54 & $2548.92^{*}$ & 0.03 & $0.22^{* *}$ \\
\hline 2002 & 0.36 & $6491.18^{* *}$ & 0.01 & $0.26^{* *}$ & 0.51 & $6751.40^{* *}$ & 0 & $0.31^{* *}$ \\
\hline 2001 & 0.47 & $3642.21^{* *}$ & $0.01^{* *}$ & $0.18^{* *}$ & 0.66 & $3585.86^{* *}$ & $(-) 0.01^{*}$ & $0.20^{* *}$ \\
\hline 2000 & 0.46 & $5895.18^{* *}$ & 0 & $0.23^{* *}$ & 0.64 & $6532.28^{* *}$ & 0.02 & $0.27^{* *}$ \\
\hline 1999 & 0.47 & $7663.17^{* *}$ & 0 & $0.27^{* *}$ & 0.44 & $11355^{* *}$ & 0.01 & $0.21^{* *}$ \\
\hline 1998 & 0.39 & $3076.98^{* *}$ & $0.04^{*}$ & $0.55^{* *}$ & 0.61 & $1,288.41$ & 0 & $0.67^{* *}$ \\
\hline 1997 & 0.61 & $7690.03^{* *}$ & 0.06 & $0.68^{* *}$ & 0.49 & $7310.69^{* *}$ & -0.06 & $0.78^{* *}$ \\
\hline 1996 & 0.71 & $5612.33^{* *}$ & 0.02 & $0.68^{* *}$ & 0.76 & $4029.66^{* *}$ & -0.01 & $0.79^{* *}$ \\
\hline 1995 & 0.63 & $6752.51^{* *}$ & 0.03 & $0.98^{* *}$ & 0.86 & $6817.70^{* *}$ & $(-) 0.09^{*}$ & $1.02^{* *}$ \\
\hline 1994 & 0.72 & $8823.37^{* *}$ & $0.01^{*}$ & $0.69^{* *}$ & 0.78 & $7133.54^{* *}$ & -0.07 & $0.73^{* *}$ \\
\hline $1994-2005$ & 0.42 & $6271.74^{* *}$ & 0 & $0.39^{* *}$ & 0.49 & $7812.98^{* *}$ & 0 & $0.34^{* *}$ \\
\hline
\end{tabular}

Variable definitions: refer to $<$ Table $2>, *(* *)$ : Significant at the $.05(.01)$ level.

Table 13. Multiple Linear Regression of Stock prices on Cash Flows/Book Value for Profit firms and Loss firms, Respectively

\begin{tabular}{|c|c|c|c|c|c|c|c|c|}
\hline \multirow{2}{*}{ Year } & \multicolumn{7}{|c|}{$\mathrm{P}_{\mathrm{t}}=\mathrm{b}_{1}+\mathrm{b}_{2} \mathrm{CF}_{\mathrm{t}} / \mathrm{S}_{\mathrm{t}}+\mathrm{b} 3 \mathrm{BV}_{\mathrm{t}-1} / \mathrm{S}_{\mathrm{t}}+\varepsilon_{\mathrm{t}}$} \\
\cline { 2 - 10 } & \multicolumn{3}{|c|}{ (A) Profit Firms } & \multicolumn{4}{|c|}{ (B) Loss Firms } \\
\cline { 2 - 10 } & Adj $\mathrm{R}^{2}$ & $\mathrm{~b} 1$ & $\mathrm{~b} 2$ & $\mathrm{~b} 3$ & Adj $\mathrm{R}^{2}$ & $\mathrm{~b} 1$ & $\mathrm{~b} 2$ & $\mathrm{~b} 3$ \\
\hline 2005 & 0.74 & $2499.83^{* *}$ & $1.31^{* *}$ & $0.39^{* *}$ & 0.6 & $1,029.10$ & $1.57^{* *}$ & $0.45^{* *}$ \\
\hline 2004 & 0.8 & $2328.54^{* *}$ & $1.53^{* *}$ & $0.19^{* *}$ & 0.34 & $4785.06^{* *}$ & $1.21^{* *}$ & $0.10^{* *}$ \\
\hline 2003 & 0.72 & $1864.89^{* *}$ & $1.43^{* *}$ & $0.08^{* *}$ & 0.44 & $1986.79^{*}$ & $1.33^{* *}$ & $0.11^{* *}$ \\
\hline 2002 & 0.42 & $5809.94^{* *}$ & $0.57^{* *}$ & $0.23^{* *}$ & 0.45 & $6842.51^{* *}$ & 0.12 & $0.30^{* *}$ \\
\hline 2001 & 0.47 & $3564.27^{* *}$ & $0.03^{* *}$ & $0.18^{* *}$ & 0.59 & $3185.57^{* *}$ & $0.48^{* *}$ & $0.16^{* *}$ \\
\hline 2000 & 0.71 & $4166.09^{* *}$ & $1.93^{* *}$ & $0.20^{* *}$ & 0.27 & $8919.35^{* *}$ & 0.26 & $0.21^{* *}$ \\
\hline 1999 & 0.38 & $8308.43^{* *}$ & $0.59^{* *}$ & $0.19^{* *}$ & 0.39 & $10785^{* *}$ & $0.59^{* *}$ & $0.15^{* *}$ \\
\hline 1998 & 0.56 & $3297.08^{* *}$ & $0.41^{* *}$ & $0.46^{* *}$ & 0.57 & $1,351.34$ & $0.35^{* *}$ & $0.58^{* *}$ \\
\hline 1997 & 0.65 & $11857^{* *}$ & $0.90^{* *}$ & $0.45^{* *}$ & 0.56 & $11065^{* *}$ & $0.69^{* *}$ & $0.56^{* *}$ \\
\hline 1996 & 0.7 & $7566.93^{* *}$ & $0.97^{* *}$ & $0.49^{* *}$ & 0.75 & $6732.42^{* *}$ & $0.96^{* *}$ & $0.54^{* *}$ \\
\hline 1995 & 0.64 & $6896.11^{* *}$ & $0.79^{* *}$ & $0.95^{* *}$ & 0.74 & $7557.17^{* *}$ & $0.81^{* *}$ & $0.92^{* *}$ \\
\hline 1994 & 0.65 & $10797^{* *}$ & $0.58^{* *}$ & $0.52^{* *}$ & 0.75 & $8436.52^{* *}$ & $0.59^{* *}$ & $0.60^{* *}$ \\
\hline $1994-2005$ & 0.62 & $7423.09^{* *}$ & $0.63^{* *}$ & $0.30^{* *}$ & 0.33 & $9869.51^{* *}$ & $0.46^{* *}$ & $0.26^{* *}$ \\
\hline
\end{tabular}

Variable definitions: refer to $<$ Table $2>, *(* *)$ : Significant at the $.05(.01)$ level. 
Table 14. Multiple Linear Regression of Stock prices on Earnings/Book Value for Earnings Managed firms and Non-Earnings Managed firms, Respectively

\begin{tabular}{|c|c|c|c|c|c|c|c|c|}
\hline \multirow[t]{2}{*}{ Year } & \multicolumn{4}{|c|}{ (A) Earnings Managed Firms } & \multicolumn{4}{|c|}{ (B) Non-Earnings Managed Firms } \\
\hline & $\operatorname{Adj} R^{2}$ & b1 & b2 & b3 & $\operatorname{Adj} R^{2}$ & b1 & b2 & b3 \\
\hline 2005 & 0.62 & 673.66 & 0.32 & $0.68 * *$ & 0.75 & $2437.25 * *$ & $1.29952 * *$ & $0.40 * *$ \\
\hline 2004 & 0.31 & $5801.51 * *$ & 0.57 & $0.37 * *$ & 0.8 & $2259.53 * *$ & $1.49 * *$ & $0.20 * *$ \\
\hline 2003 & 0.43 & $1,246.33$ & 0.04 & $0.31 * *$ & 0.71 & $1934.21 * *$ & $1.40 * *$ & $0.09^{* *}$ \\
\hline 2002 & 0.51 & $7005.80 * *$ & 0 & $0.31 * *$ & 0.42 & $5846.15^{* *}$ & $0.55^{* *}$ & $0.23^{* *}$ \\
\hline 2001 & 0.66 & $4088.93 * *$ & 0 & $0.20 * *$ & 0.47 & $3724.68 * *$ & $0.12 *$ & $0.16^{* *}$ \\
\hline 2000 & 0.71 & $6197.91 * *$ & 0.02 & $0.28 * *$ & 0.7 & $4956.79 * *$ & $1.82 * *$ & $0.22 * *$ \\
\hline 1999 & 0.48 & $11691 * *$ & 0.01 & $0.21 * *$ & 0.36 & $8848.15^{* *}$ & $0.59 * *$ & $0.17 * *$ \\
\hline 1998 & 0.62 & $1,865.71$ & 0.01 & $0.68 * *$ & 0.56 & $3221.90 * *$ & $0.36 * *$ & $0.48^{* *}$ \\
\hline 1997 & 0.54 & $6247.15^{*}$ & -0.03 & $0.86^{* *}$ & 0.63 & $12311^{* *}$ & $0.84 * *$ & $0.46^{* *}$ \\
\hline 1996 & 0.81 & $4182.55^{* *}$ & -0.01 & $0.82 * *$ & 0.7 & $8016.69 * *$ & $0.93 * *$ & $0.48^{* *}$ \\
\hline 1995 & 0.87 & $6,131.37$ & -0.34 & 1.03 & 0.65 & $7165.64 * *$ & $0.77 * *$ & $0.94 * *$ \\
\hline 1994 & 0.79 & $6896.37 * *$ & -0.07 & $0.73 * *$ & 0.66 & $10714 * *$ & $0.58 * *$ & $0.53^{* *}$ \\
\hline 1994-2005 & 0.52 & $7890.25^{* *}$ & 0.01 & $0.35 * *$ & 0.6 & $7807.65^{* *}$ & $0.61 * *$ & $0.30^{* *}$ \\
\hline
\end{tabular}

Variable definitions: refer to <Table 2>,* (**): Significant at the $.05(.01)$ level.

Table 15. Multiple Linear Regression of Stock prices on Cash Flows/Book Value for Earnings Managed firms and Non-Earnings Managed firms, Respectively

\begin{tabular}{|c|c|c|c|c|c|c|c|c|}
\hline \multirow{3}{*}{ Year } & \multicolumn{8}{|c|}{$\mathrm{P}_{\mathrm{t}}=\mathrm{b}_{1}+\mathrm{b}_{2} \mathrm{CF}_{\mathrm{t}} / \mathrm{S}_{\mathrm{t}}+\mathrm{b} 3 \mathrm{BV} \mathrm{V}_{\mathrm{t}-1} / \mathrm{S}_{\mathrm{t}}+\varepsilon_{\mathrm{t}}$} \\
\hline & \multicolumn{4}{|c|}{ (A) Earnings Managed Firms } & \multicolumn{4}{|c|}{ (B) Non-Earnings Managed Firms } \\
\hline & $\operatorname{Adj} R^{2}$ & b1 & $\mathrm{b} 2$ & b3 & $\operatorname{Adj} R^{2}$ & b1 & $\mathrm{b} 2$ & b3 \\
\hline 2005 & 0.56 & 960.46 & $1.73^{* *}$ & $0.43 * *$ & 0.75 & $2437.25 * *$ & $1.30 * *$ & $0.40 * *$ \\
\hline 2004 & 0.33 & $5032.69 * *$ & $1.47 * *$ & 0.05 & 0.8 & $2259.53 * *$ & $1.49^{* *}$ & $0.20 * *$ \\
\hline 2003 & 0.45 & $1,717.73$ & $1.82 * *$ & 0.05 & 0.71 & $1934.21 * *$ & $1.40^{* *}$ & $0.09 * *$ \\
\hline 2002 & 0.44 & $7142.52 * *$ & 0.12 & $0.30 * *$ & 0.42 & $5846.15^{* *}$ & $0.55^{* *}$ & $0.23 * *$ \\
\hline 2001 & 0.59 & $3013.32 * *$ & $0.33^{*}$ & $0.19 * *$ & 0.47 & $3724.68 * *$ & $0.12 *$ & $0.16^{* *}$ \\
\hline 2000 & 0.26 & $8900.72 * *$ & 0.28 & $0.21 * *$ & 0.7 & $4956.79 * *$ & $1.82 * *$ & $0.22 * *$ \\
\hline 1999 & 0.4 & $9857.94 * *$ & $0.67 * *$ & $0.16^{* *}$ & 0.36 & $8848.15^{* *}$ & $0.59 * *$ & $0.17 * *$ \\
\hline 1998 & 0.56 & 652.56 & $0.42 * *$ & $0.57 * *$ & 0.56 & $3221.90 * *$ & $0.36^{* *}$ & $0.48^{* *}$ \\
\hline 1997 & 0.58 & $8977.13^{* *}$ & $0.91 * *$ & $0.56^{* *}$ & 0.63 & $12311 * *$ & $0.84 * *$ & $0.46^{* *}$ \\
\hline 1996 & 0.78 & $4154.97 * *$ & $1.21 * *$ & $0.58^{* *}$ & 0.7 & $8016.69 * *$ & $0.93^{* *}$ & $0.48^{* *}$ \\
\hline 1995 & 0.74 & $6111.98^{*}$ & $0.85^{* *}$ & $0.97 * *$ & 0.65 & $7165.64 * *$ & $0.77^{* *}$ & $0.94 * *$ \\
\hline 1994 & 0.74 & $7776.93 * *$ & $0.62 * *$ & $0.61 * *$ & 0.66 & $10714 * *$ & $0.58^{* *}$ & $0.53 * *$ \\
\hline 1994-2005 & 0.37 & $8664.83 * *$ & $0.55^{* *}$ & $0.27 * *$ & 0.6 & $7807.65 * *$ & $0.61 * *$ & $0.30 * *$ \\
\hline
\end{tabular}

Variable definitions: refer to <Table 2>, * (**): Significant at the $.05(.01)$ level. 